\title{
Collaboration System and Digital Business Efficiency in the Accounting Information System Perspective (Case Study Banyuwangimall.com)
}

\author{
A.A.G.S. Utama* \& Y. Setyowati \\ Airlangga University \\ Surabaya, Indonesia \\ *gde.agung@ feb.unair.ac.id
}

\begin{abstract}
This study aims to design a new digital commerce system by involving UMKM through ecommerce platform banyuwangimall.com in perspective of accounting information system. The point of view of accounting information systems through e-commerce is growing rapidly and provides many new challenges. One of the challenges is the presence of web 2.0 generation that involves social media. These challenges lead to the emergence of the term social commerce which means that trading can be done through social media. On the other hand, electronic commerce or ecommerce presents a shorter trading system but less improves the relationship between sellers and buyers. The presence of s-commerce in value will be a good trading method for producers and consumers, so it can be a threat to the sustainability of e-commerce. Turning the threat into an opportunity then this research intends to design a collaboration system between ecommerce and s-commerce, which can be applied to the site banyuwangimall.com. it is expected that the results of this study will contribute to expedite transactions and increase sales on the site banyuwangimall.com in which is the perpetrators of SMEs in all Banyuwangi district.
\end{abstract}

\section{Keywords-Collaboration System; Digital Business;} Efficiency; Accounting Information

\section{INTRODUCTION}

Digital business is also used as electronic business (ebusiness) is the use of digital technology and the Internet in executing most of the business processes of a company, and electronic commerce (e- commerce) is part of e-business that focuses on a series of selling activities -buy [1]. E-commerce marketing can improve the level of corporate distribution and communication efficiency in the practice of B2B (business-tobusiness) exports [2]. The results of interviews with users and also admin from e-commerce site banyu wangimall.com said that the existence of e- commerce buying and selling activities to be very effective and efficient because it does not need to meet in person. Site banyuwangimall.com is an e- commerce platform managed by the government of Banyuwangi Regency under the auspices of the Office of Cooperatives and Micro Enterprises to sell goods and services results of SMEs Banyuwangi community.

But nowadays there is a new term with online business through social media that is Social Commerce. Social commerce is an evolution of e-commerce that combines social activity by incorporating social media technologies into e-commerce sites [3]. S-Commerce is defined as a new way or way of trading through collaboration, participation and interaction between all parties in the value chain [4]. Social commerce is a phenomenon derived from social media practices and Web 2.0 technology, making it a popular tool for sharing information with consumers [5].

So s-commerce is needed as a driver of e-commerce in the sense to provide support system. S-commerce is considered more appropriate to the characteristics and culture of Indonesian society. First appeared s- commerce in 2005 with the launch of Yahoo! Shoposphere. Until the year 2015, s-commerce revenue of $\$ 30$ billion [6]. In addition to the practice of buying and selling online, usually the seller also performs the process of buying and selling as in general, which distinguishes only the seller- buyer does not meet directly as in traditional markets, but by way of direct communication either through personal networks, chats, or phone.

Like most e-commerce sites, banyuwangimall.com also uses the system as its main actor. Buyers who make transactions with banyuwangimall.com must go through a series of login or login process into the system. Prospective buyers must login first, to further make the process of ordering and payment. Payment at banyuwangi mall, has 2 different methods, first by way of e-commerce in general is by inserting a credit card or debit card. Both payments are made via ATM, or transfer manually.

On the other hand there are social media like Instagram, facebook, twitter, path, and line that can also be used by users to do business online. Using social media to do business or doing s-commerce, be a good choice for some people. Because through social media in addition to promoting directly, between buyers and sellers can also make the process of price bargaining. The simplest example is instagram, many features are offered in instagram, such as direct message, search \& explore, short video, digital filters for photos or videos to upload, tagging, comment \& linking that support instagram users for access his account at least 1 time in 1 hour [7]. The intensity of instagram access that so often causes the seller to easily do marketing or advertising related products/services to be sold, and the features provided 
also facilitate communication between sellers and buyers, it decreases operational costs [8]. Competition is already higher among business organizations would need more useful information to make decisions, both accounting information and non-accounting information. The current accounting information generated is not just a profit/loss statement, all information generated by the current information system should support the binding of productivity, efficiency and control that is critical to the face of competition. The function of the financial accounting system is divided into two, namely for external parties and internal organization or company. External parties are creditors, Investors, government agencies, competitors, labor unions, stakeholders, customers and suppliers, for internal parties is the management of the company ranging from operational employees, operational management, middle management and top management [9] [10].

E-commerce is considered not able to meet and adjust to the business environment in Indonesia, so that consumer behavior will tend to move on s- commerce. In accordance with the results of the research [11], the underlying cause is the low efficiency in transactions, a long process when consumers will access the e-commerce site and the causes of the displacement of consumer behavior include social presence, social support, social benefits, and performance, attract consumers to move to scommerce. It is also supported by the results of research [12] stating that social support directly affects the quality of relationships between sellers and buyers. Regarding the acceptance of a s-commerce framework or the idea of scommerce in Saudi Arabia is positive, resulting in expectations, hedonic motivation, customs, price saving orientation, social support, positive values on consumer behavior [13]

Previous studies related to the efficient use of ecommerce in the practice of B2B [14] and the efficient use of ecommerce in B2C (business to cutomers) practice [15], both proving that e- can improve efficiency in business activities. On the other, e-commerce has begun to be abandoned, and turned to s- commerce [11] [12]. Research often focuses on the idea of scommerce, the acceptance of s-commerce, the shifting of ecommerce consumer behavior toward s- commerce, s-commerce business model, s- commerce website design and adopting scommerce strategy [16]. So far the issue of efficiency of ecommerce and s-commerce is only about the practice of buying and selling, not yet up to the efficiency in accounting information generated by both types of digital business.

The position of banyuwangimall.com as e- commerce managed by the government, has not provided enough space to conduct transactions in the context of social commerce, so far still in electronic commerce that has been increasingly rarely used because of switching to s-commerce. Cases that occur on banyuwangimall.com one of them has not been able to provide information both in terms of management and accounting, so it can not provide enough information to make decisions.

The contribution of this research lies in the innovation that will improve banyuwangimall.com system and facilitate the transaction activity between seller and buyer. As a platform used for MSME facilities in Banyuwangi this innovation will certainly contribute to the community's income and economic growth.

To understand the problems that occur in banyu- wangimall.com and find a suitable solution, then compiled the problem formulation as follows: "How to design a collaborative system of social media technologies and the efficiency of integrated financial reports on e-commerce site banyuwangimall.com?"

\section{Literature REVIEW}

\section{A). Digital Business}

In the modern era of the term digital business is certainly not foreign anymore, a lot of business activities that currently use the digital network in its activities. Digital business as a new business design that not only connects people to business, but also connects with other things to lead in revenue and efficiency [17]. Digital business helps to remove the existing barriers industry segments as well as to create a new chain of values and opportunities that traditional businesses can not offer. More simple digital business activity is often referred to as "ebusiness" or electronic business. E-business not just the buying and selling of goods and services, but also doing all kinds of online businesses such as serving customers, collaborating with business partners, e-learning, and conducting electronic transactions inside organization [18]. E-business refers to the use of digital technology and the Internet in carrying out most of the company's business activities [1]. E-business refers to the usefulness of information technology in various aspects of the company's business [19]. Based on the definition it can be concluded that business activities that occur in banyuwangimall.com is part from ebusiness in the form more specifically for the activities of buying and selling UMKM products commonly called e-commerce.

\section{B) E-Commerce}

E-commerce is part of an e-business that focuses on buying and selling goods and services using the internet network [1]. Electronic commerce or e-commerce is part of e-business [1] [10]. The benefits of e-commerce can lead to significant changes in business ways and have a positive impact on company operations resulting in a competitive advantage for companies using e-commerce as well as for more efficient government and nonprofit organizations [18]. E-commerce grow fast is a unique character of the development of Internet technology, namely (1). There is everywhere (Ubiquity) (2). Global Reach (3). Standard Universal (4). Rich benefits (Richness) (5) .Interaktif (6). Information Density (7) .Personalization (Personalization) (8) Technology [1].

\section{C) Social Commerce (S-Commerce)}

Social Business or social business is the use of social networking platforms, including facebook, twitter, and internal corporate social tools, to engage their workers, customers and suppliers in one network [1]. This new medium allows workers to organize profiles, form groups or groups, follow each other and update status. The purpose of social business is to deepen the interaction with groups or groups both within and outside the company to accelerate and improve the dissemination of information, innovation and decision making. The inner social business forum [18] defines that social business is an organization that is strategically, technologically and systematically processed to persuade all individuals within its ecosystem (workers, customers, partners, and suppliers) to 
maximize value foreclosure . The second generation of $\mathrm{E}$ commerce that emerged with web 2.0 tools, namely social media, social networking, and virtual worlds, referred to as social computing. In social computing and commerce, people work together through the internet, consulting with specialists in their fields, detecting the location of goods and services, and getting recommendations from friends. Web 2.0 is the second generation of the Internet, based on its tools and services that make it easy for users to generate new content, sharing media, communications and collaboration through innovation [18]. The presence of Web 2.0 became the basis of the development of the social Web. Many people equate Web 2.0 with social media and vice versa. Social media is defined as the audio, images, online text, and video content created by people using the web 2.0 platform and its tools for social interaction and conversation, especially to share opinions, experiences, knowledge, and perceptions [18] Social commerce is a phenomenon derived from social media practices and Web 2.0 technology, making it a popular tool for sharing information with consumers [5]. Social commerce deals with e-commerce transactions conducted using social media. Some experts consider social commerce to be part of e- commerce, specifically defined as a combination of ecommerce and e-marketing, technology support and social media content.

\section{D) System Collaboration}

Collaboration by Laudon [1] is working with others to achieve mutual benefits and clear goals. Collaboration focuses on the task or completes the mission and usually in the businessfield, between businesses or other organizations. It is common knowledge between the academic and business world that the more businesses collaborate, the more successful, and the collaboration between companies is more valuable than ever. The use of social technology within the company and between companies has the potential to increase productivity between $20 \%-25 \%$ of worker interactions.

\section{E) Accounting Information System}

Accounting Information System is a collection of resources owned by organizations or companies whether human and or equipment designed to transform financial data into information [19]. Accounting information system can work manually or computerized, the flow in the system from the input and then processed to produce the output of information. Based on these definitions, accounting is included in the information system because the accounting information system (SIA) performs the collection, recording, storage and processing of accounting with other data to generate information for decision makers. The role of accounting information systems in generating reliable financial information is increasingly important after a well-known and disputed financial scandal around the world. The strong relationship between financial data, information systems and income quality is based on the discipline of IT governance and compliance, which aims to define safe processes and organizational architecture as an accounting information system environment, to manage the reliability of processed financial data [20]. The transaction process in the accounting information system, one of which is the sales cycle and cash receipt cycle that will be the focus of this research [21]. The rapidly growing e- commerce practices in Indonesia, including banyuwangimall.com, require accounting information systems to provide accurate and precise financial information. Especially for consideration in making decisions and generate financial statements of an entity. This research intends to design collaboration system design and improve the efficiency of digital business in view of accounting information system. The theory of accounting information system is focused on sales and cash receipts cycle, because the case study used is the buying and selling activities through e-commerce site banyuwangimall.com.

\section{RESEARCH METHOD}

\section{A) Research approach}

The research methodology is a way to find answers to a problem [22]. Research methods for the field of information systems is still relatively new, so it needs attention in determining the area of information systems. Starting from the design and implementation (technical perspectives) as well as the structure and impact of the information system (social perspectives). This research is exploratory research that will be conducted in Banyuwangi Regency by using triangulation method. Qualitative methods are used to investigate a social phenomenon and human problems in everyday life [23]. The exploratory approach means that the researcher performs direct observation on the object under study [24], which in this case the object of research is ecommercee site banyuwangimall.com., Because the case study used is the buying and selling activities through e-commerce site banyuwangimall.com.

\section{B) Types and Data Sources}

Types of data used in this study are primary and secondary data. Primary data is data obtained or collected directly in the field by the person conducting the research or the person concerned who needs it. This primary data is also called original data or new data. Primary data in this study were obtained from interviews and through documentation obtained from the perpetrators of SMEs and related parties in banyuwangimall.com directly without third parties. Secondary data is data that is not obtained directly from resource person, secondary data become supporter of primary data. In this study secondary data obtained from participative observation passively in the documented. This secondary data can be in the form of a review of news or issues that are likely to be circulated or contained in mass media to support the primary data.

\section{C) Data Collection Procedures}

In general there are several data collection techniques in case studies namely documentation, archival records, interviews, direct observation, participant observations, and physical devices and devices [23]. Data collection techniques used in this study are:

\section{1) Passive Participatory Oversight}

Researchers come to the subject of research and make observations but are not involved in the business operations. participative passive observation was chosen in order to illustrate the research object of this research more clearly and detail. This research made an observation by looking at the system in banyuwangimall.com especially on reports generated system both from the side of MSMEs and admin who operate the site. And observation on the customer by providing the possibility if banyuwan- gimall.com e-commerce site in collaboration with social media technology to facilitate the interaction between users of the site.

\section{2) Interview}

This study uses structured interview methods where researchers have prepared research instruments in the form of 
questions on the topic to be examined in writing. These structured interview respondents were given the same question and the researchers recorded the interview results. This interview is addressed to the parties involved, ranging from MSMEs, admin and Head of the field in the Office of Cooperatives as leaders who are eligible to take decisions.

The reason why this interview was chosen because the interview can describe as a whole and comprehensive about the data needed in this study. In addition, with interviews also the data required in this study can be explored or known more deeply than ever before.

\section{3) Documentation}

This documentation was chosen because through documentation it can reinforce the data found in the field research, so the data found in the research is stronger in its argument and its proof.

\section{DISCUSSION}

\section{A) Overview of Digital Bussiness}

Digital business or commonly referred to as electronic business (e-business) is the use of digital technology and the Internet in executing most of the business processes of a company. Further electronic commerce (e-commerce) is part of e-business that focuses on a series of trading activities [1]. The results of the study Gregory [2] prove that e-commerce marketing can improve the level of corporate distribution and communication efficiency in the practice of B2B (bu- sines-tobusiness) exports. As time passes, digital business grows very fast, like technological development in general. The emergence of web 2.0 that became the beginning of the famous social media has a considerable influence. To this day emerged a development of the new e-commerce, which is usually called social commerce or s-commerce.

Social commerce is a phenomenon derived from social media practices and Web 2.0 technology, making it a popular tool for sharing information with consumers [5]. The emergence of new innovations in the form of s-commerce is causing the existence of e-commerce has decreased. Many research results that one of the weaknesses of e- commerce is the level of confidence that customer always declining, but with the presence of social commerce, the weakness can be eliminated. The method of s-commerce, more emphasis on trade as e-commerce involving customers and sellers can communicate well indirectly.

Related to the weaknesses of e-commerce is also perceived by the platform banyuwangimall.com which became one of the e-commerce platform under the auspices of local governments. The results of interviews with admin banyuwangimall.com revealed that most customers do not complete the transaction process only until the order. On the other side of the order through the system, will be recorded automatically when it is paid, and the seller will only send goods after receiving confirmation of payment. Ba- nyuwangimall.com system can not connect cyberspace or real world between traders and sellers. This system is managed by the Cooperative Office of Banyuwangi Regency in the form of Creative House which becomes the liaison for the perpetrators of SMEs as Sellers and customers. As a bridge that connects the transaction process, the creative house also acts as admin banyuwangimall.com does not profit.

However, due to the development of digital business or digital commerce into e-commerce and s- commerce admitted banyuwangimall.com admitted great influence, because some UMKM can not access through social media, on the other hand more interested customers to shopping in s-commerce. It is supported by the opinion of one of the perpetrators of MSMEs or traders who claim to have difficult access to direct customers so can not do the promotion maximally.

\section{B) Overview of Banyuwangimall}

The e-commerce platform managed by the local government of Banyuwangi Regency, by utilizing corporate social responsibility (CSR) program from BNI as system provider. The government of Banyu- wangi Regency has several excellent programs, one of them is the marketing development of Micro, Small and Medium Enterprises (UMKM) products online. Based on BPS data in 2010 the number of SMEs in Banyuwangi around $\pm 131,304$ and increased significantly in 2015 to $\pm 296,706$. The types of products produced ranging from batik, fashion, handicrafts, processed foods, accessories, souvenirs, and furniture.

Some of the problems of SMEs that become the focus of Banyuwangi district government at this time other than the capital of product marketing and information technology knowledge. Related issues - the problem is qualified $20 \%$ capital, 45\% marketing, and 35\% Knowledge of Information Technology. In order to improve the economy, to increase market share, to expand the media of communication and promotion of local product of creative work of UMKM, the idea came to collaborate systematically and integratively online between various parties including Banyuwangi Regency Government, UMKM and Stakeholder others through an innovation. This innovation is built in the form of market place (www.banyuwangi-mall.com). Through ba- nyuwangi-mall.com UMKM Banyuwangi products are known by national and international markets.

Like most e-commerce sites, banyuwangimall.com also uses the system as its main actor. Buyers who make transactions with banyuwangimall.com must go through a series of login or login process into the system. Prospective buyers must login first, to further make the process of ordering and payment. Payment at banyuwangi mall, has 2 different methods, first by way of e-commerce in general is by inserting a credit card or debit card. Both payments are made via ATM, or transfer manually.

Based on the results of interviews before the research conducted with admin banyuwangimall.com revealed that the advantages of e-commerce is managed by the government does not take profit or profit from the practice of buying and selling, so the price displayed on the site banyuwangimall.com is the original price of the manufacturer or UMKM . And the existing weakness is banyuwangimall.com system can not connect directly between seller and buyer, if buyer or customer want to order in large quantity hence have to contact admin banyuwangimall.com to ask seller information.

\section{1) Power Administration}

- Monitor sales transactions;

- Inform and promote creative homes (banyuwangimall.com) through social media (twitter, facebook etc);

\section{- Customer Service;}

- Providing services to Micro Business actors related to product quality, product photo, product packaging and product delivery;

- Report activity results;

- Other tasks related to the creative house and banyuwangimall.com

\section{2) Graphic Designs}

- Updating product content on the website; 
- Shoot photos of products;

- Editing product photos;

- Uploading product photos;

- Create a Design Banner;

- Report activity results;

- Other tasks related to the creative house and banyuwangimall.com

\section{3.) Packaging Design Power}

- Create a master design file

- Designing product packaging according to market needs

- Research of renewable packaging design (based on materials and products)

- Report activity results;

- Other tasks related to the creative house and banyuwangimall.com

\section{4) Media Parts}

- Preparation of the profile of SMEs Featured

- Make Narration of website content and social media

- Develop a promotional calendar (social media and web)

- Report activity results;

- Other tasks related to the creative house and banyuwangimall.com

Through the job desk is known that in the media has been related to the writing of promotional content through social media. But it can not connect directly between customer and merchant, in other words still through intermediary, and transaction process can not be done through ordering in social media. Only transactions made through banyuwangimall.com site that can be recorded, so that required transaction features are also incorporated in the system banyuwan- gimall.com to be recorded and can be used for further development purposes.

\section{C) Applied System Analysis}

The system running as discussed earlier still has some weaknesses. Associated with the record data generated system is still raw data, and still need to be re-processed to be used both as a reference and consideration materials. The rigid system can not involve direct transactions between the seller and the developer. The existence of admin banyuwangi- mall.com is very helpful in technical terms, but in terms of transactions should not, because it will be more effective if the customer can directly communicate with the seller, so admin banyuwangi- mall.com will be more effective in developing the system, content and monitor transactions. Testimonials or customer opinions about the product or service used can not be used as a powerful weapon for promotion. The banyuwangimall.com e-commerce platform is more aimed at promotional sites, with one-door transaction services. Human resources involved in this system starting from admin banyu- wangimall.com able to run well, and has a linear educational background that is Information Technology

\section{D) Social Commerce System Design}

Broadly speaking the input on the system is still the same, but will be developed on the part of the system that features chat group, share, keep, and self promotion. These additional features are not a counter-system but rather a support system. Still using the old business process, but will be developed with additional features where customers and sellers can communicate and transact directly.

The Business Process of Digital Commerce in Banyuwangimall is described as follows:
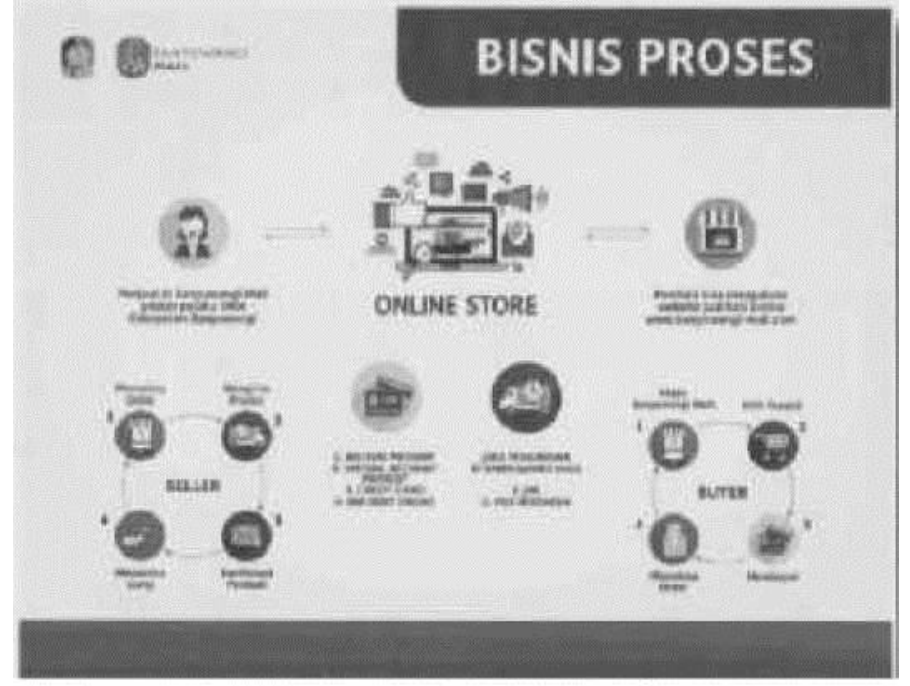

Fig. 1 Business Process

The process starts from customers who access on banyuwangimall.com by registering first, and then login to be able to conduct transactions, to choose products or services in want. After selecting the products or services that suit the customer ordering through the system Booking through the system will be automatically recorded and can be seen by admin banyuwangimall.com and seller. Once the order is registered, the customer or buyer makes payment according to the goods or services in the message. Orders that have been made further payment will be followed up by delivering goods or services. Here is the payment process available at banyuwangi- mall.com Payment can only be made through BNI Bank account as a media partner and also party that provides banyuwangimall.com system. The process also responds after the buyer makes a payment or receives the goods. But so far the customer has not been able to testimony or direct response. Through this research will be designed a new system that can reduce existing weaknesses.

\section{CONCLUSIONS}

Based on the above discussion, the following conclusions can be drawn:

- The rapid technological development seen with the emergence of web 2.0 and the beginning of the emergence of a new digital commerce method of social commerce (scommerce). The existence of s-commerce became one of the trends that then beat e-commerce, because some of the shortcomings of e-commerce that can be perfected with scommerce.

- It also happens on the e-commerce platform run by the government of Banyuwangi regency is banyuwangimall.com .. One of the weaknesses that occur is the difficulty of communication between sellers and buyers directly. On the other hand such communication is very important. Given this then banyuwangimall.com system should also do system development.

- Add chat group feature, self-promoting, keep, and share that connect with each social media seller and buyer account. 
This will result in a wider market. The design of this system will not change the old system layout, it will have little development to add the existence of web 2.0 through social media

\section{REFERENCES}

[1] Laudon, K.C. \& Laudon, J.P., 2016. Management Information Systems: Managing the Digital Firm 14th Editi. N. Sam, ed., England: Pearson Education Limited.

[2] Gregory, G.D., Ngo, L.V. \& Karavdic, M., 2017. Developing e-commerce marketing capabilities and ef fi ciencies for enhanced performance in business-to-business export ventures. Industrial Marketing Management.

[3] Lu, B., Fan, W. \& Zhou, M., 2016. Computers in Human Behavior Social presence, trust, and social commerce purchase intention: An empirical research. Computers in Human Behavior, 56, pp.225-237.

[4] Baghdadi, Y., 2016. A framework for social commerce design. Information Systems, 60, pp.95-113. doi:http://dx.doi.org/10.1016/_j.is.2016.03.007.

[5] Lin, X., Li, Y. \& Wang, X., 2017. Social commerce research : Definition, research themes and the trends. International Journal of Information Management, 37(3), pp.190201.

[6] Hall, J.A., 2011. Accounting Information Systems SEVENTH EDITION Seventh Ed. R. Dewey, ed., USA: Cengage Learning.

[7] Bodnar, G.H. \& Hopwood, W.S., 2013. Accounting Information Systems Eleventh Edition 11 th. Ed. S. Yagan, ed., New Jersey: Pearson Education, Inc.

[8] Li, C. \& Ku, Y., 2017. The Power of a Thumbs-Up : Will E-commerce Switch to Social Commerce? Information \& Management.

[9] Rahayu, P., Fitriah Ayuning Budi, N. \& Indra Sensue, D., 2017. Pengaruh Dukungan dan Hubungan Sosial terhadap Niat Membeli Produk pada Social Commerce. Journal of Information Systems, 13, pp.21-30

[10] Sheikh, Z. et al., 2017. Telematics and Informatics Acceptance of social commerce framework in Saudi Arabia. Telematics and Informatics, (June), pp.0-1.

[11] Leung, K.H. et al., 2017. A B2C E-Commerce Intelligent System for Reengineering the E- order Fulfilment process. Expert Systems with Applications An International Journal.

[12] Connell, K.O., 2015. Digital Business Transformation : Disrupt To Win. , (June).

[13] Turban, E., Strauss, J. \& Lai, L., 2016. Social Commerce, Switzerland: Springer International Publishing.

[14] Mancini, D., Vaassen, E.H.J. \& Dameri, R.P., 2013. Accounting Information Systems for Decision Making, London: Springer

[15] Hall, J.A., 2011. Accounting Information Systems SEVENTH EDITION Seventh Ed. R. Dewey, ed., USA: Cengage Learning.

[16] Taylor, S.J., Bogdan, R. \& DeVault, M.L., 2016. Introduction to Qualitative Research Methods 4th ed., New Jersey: John Wiley \& Sons, Inc.

[17] Yin, R.K., 2011. Qualitative Research from Start to Finish, New York: The Guilford Press.

[18] Creswell, J.W., 2014. Research-Design-Qualitative- Quantitative-andMixed-Method- Approaches.pdf, United States of America: SAGE Publications, Inc.

[19] Simkin, M.G., Bagranoff, N.A. \& Norman, C.S., 2010. Core Concepts of Accounting Information Systems 11th ed., United States of America: John Wiley \& Sons, Inc.

[20] Whitten, J. \& Bentley, L., 2007. Systems Analysis and Design Methods 7th editio. P. Duchan, ed., McGraw-Hill Companies, Inc.

[21] Ali, A., 2012. A Framework for Using Cost-Benefit Analysis in Making the Case for Software Upgrade. , 9

[22] Susanto, A., 2017. Sistem Informasi Akuntansi: Pemahaman Konsep Secara Terpadu Edisi Pert., Bandung: Lingga jaya.

[23] Taylor, S.J., Bogdan, R. \& DeVault, M.L., 2016. Introduction to Qualitative Research Methods 4th ed., New Jersey: John Wiley \& Sons, Inc.

[24] Lu, B., Fan, W. \& Zhou, M., 2016. Computers in Human Behavior Social presence, trust, and social commerce purchase intention: An empirical research. Computers in Human Behavior, 56, pp.225) 